\title{
Yan Song \& Chengri Ding (eds), Urbanization in China: Critical Issues in an Era of Rapid Growth
}

Cambridge (mass.), Lincoln Institute of Land Policy, 2007, 302 pp.

Nicolas Douay

\section{OpenEdition}

\section{Journals}

Electronic version

URL: http://journals.openedition.org/chinaperspectives/4761

DOI: 10.4000/chinaperspectives.4761

ISSN: 1996-4617

\section{Publisher}

Centre d'étude français sur la Chine contemporaine

Printed version

Date of publication: 1 December 2008

Number of pages: 116-118

ISSN: 2070-3449

\section{Electronic reference}

Nicolas Douay, "Yan Song \& Chengri Ding (eds), Urbanization in China: Critical Issues in an Era of Rapid Growth », China Perspectives [Online], 2008/4 | 2008, Online since 01 December 2008,

connection on 24 September 2020. URL : http://journals.openedition.org/chinaperspectives/4761 ; DOI : https://doi.org/10.4000/chinaperspectives.4761

This text was automatically generated on 24 September 2020 .

(c) All rights reserved 


\title{
Yan Song \& Chengri Ding (eds), Urbanization in China: Critical Issues in an Era of Rapid Growth
}

Cambridge (mass.), Lincoln Institute of Land Policy, 2007, 302 pp.

\author{
Nicolas Douay
}

1 Between 1978 and 2004, the number of urban dwellers in China rose from 170 million to 540 million, that is to say, from 17.9 percent of the total population to 41.8 percent. The authors of this book inform us that by 2020 this proportion of urban dwellers is set to reach 55 percent, while China's GDP may well have quadrupled.

2 This volume is the outcome of a research programme on China at the Lincoln Institute of Land Policy in Cambridge, Massachusetts. It follows a conference held in 2006 to mark the end of the first five years of the programme.

3 The main argument advanced by this collective work is that urbanisation is a multidimensional process. The different facets of this phenomenon are largely to be explained by the context in which the transformation of the Chinese economy took place as it moved to a socialist market economy, as well as by other historical, political, and institutional factors. In addition to these, the major role played by the different spatial and temporal scales specific to China explains the importance of the issues confronting the actors in its urban development process.

The main concern of this volume as edited by Yan Song and Chengri Ding is to present the major trends and issues around urbanisation in China, and above all to pinpoint the principal problem areas that have arisen in connection with this transformation. In the first place it is a question of the management, equipment, and development of the physical urban space itself, along with the policies needed for controlling it. In addition to these questions, there is the problem of land policy and the regulations concerning its use. Next, there is the migration between the countryside and the cities, which can have major social repercussions. Finally, local financial measures seem to be decisive for ensuring the development of infrastructure, and therefore for urban development in general. These four categories correspond to the four sections of the work, which are 
in turn connected to the different fields of research at the Lincoln Institute. Although the themes covered by these four sections cover a wide range of urban issues affecting China, there are some notable gaps, particularly with regard to policy areas that could have been more deeply explored, for example by studying the processes of urban planning.

The first section deals with the way in which urban management handles the process of urban expansion. In general, the different contributors emphasise the growing urban spread and the difficulties in responding to it with co-ordinated and efficient regulations on land use, urban policy, and the provision of public transport.

In the opening chapter, Tingwei Zhang reviews the different models for urban development in China. He gives a very pertinent presentation of the case of Shanghai through his version of the schema provided by the Chicago school of urban sociology. His accompanying analysis sets out a typology of urban spaces, distinguishing between those under renewal (such as the Bund), those under development (such as Pudong), and those that are largely ignored. This section has echoes of Jacques Donzelot's work on "the three-speed city: relegation, peripheral urbanisation, and gentrification." In Chapter Two, Ming Zhang examines the "value capture" mechanisms with regard to projects that integrate urban management and transport policies in Hong Kong, Taipei, and Shanghai. In Chapter Three, Paul Cheshire studies the logic of the "price signals" that are supposed to send a message to consumers and/or producers. He argues that they should be implemented in China, and he explains the extent to which they would enable better control over the property market.

7 The second section deals with policies on land use. While these policies are essential for ensuring urban growth, they encounter many problems on the ground. These concern the question of protecting agricultural activity and, in more general terms, the issues of rural development in the face of urban expansion.

In Chapter Four, Chengri Ding looks at the policies and practices of land acquisition. These are also approached in Chapter Five, by Erik Lichtenberg and Chengri Ding, through a study of the policies for protecting agricultural areas. In Chapter Six, within this same perspective, Robert Ash deals with the procedures for regulating the use of arable land resources in the context of sustainable development.

9 The third section of this volume is devoted to migration between town and countryside, and its social consequences. The migrants' needs, particularly for housing, have too often been neglected. So it is important to pay them greater attention in the long term, with regard not only to housing needs but also to social security and access to a balanced urban labour market capable of providing jobs for all.

10 In Chapter Seven, Yan Song, Yves Zenou, and Chengri Ding inspect the urbanisation of the villages, together with the problem of providing urban housing to migrants from a rural background. Their concept of an urbanising village, or a village within a town, is an original one that allows them to give an account of the impact of migration on the shape of Chinese cities. Michael Leaf, in Chapter Eight, illustrates this concept through his case study of Chengzhongcun. Roberto G. Quercia and Yan Song follow this in Chapter Nine by focusing on the living conditions of rural migrants and reflecting on lessons to be drawn from the American experience. Finally, in Chapter Ten, Jeffrey S. Zax questions the efficiency of the urban labour markets. 
11 The fourth section is concerned with the role of local finance in the urbanisation project, which also brings up a variety of issues. The contributors to this section respond by suggesting new strategies to secure sources of income that would be more transparent, structured, and reliable. Moreover, they emphasise that higher infrastructural standards, particularly with regard to environmental protection, are capable of supporting the competitiveness of China's cities, both in the growing global arena and in the field of domestic inter-city competition.

In Chapter Eleven, Randall Crane studies the issues of public finance in urban development, and in Chapter Twelve Weiping Wu pays particular attention to financial support for urban infrastructural projects. Finally, in Chapter Thirteen, Bing Wang and Richard Peiser explain the failures of the credit system in the context of China's economic transition.

13 In their conclusion, Yan Song and Chengri Ding refer back to the variety of different issues raised in the volume, and insist on the need to define clear perspectives for a sustainable and rational development that would harmonise the needs of the towns with those of the countryside.

14 It is regrettable that the authors do not revisit this idea of harmonious urban development, which the government is currently putting forward as the model to be followed. This is an idea that calls for deeper analyses in order to explore what it really means as well as the processes that may be involved. The question is whether this model actually provides a new reference point for China's urban policies. Are we facing a Chinese version of the western concept of sustainable development? Or is it a mere slogan, deploying new terminology to cover up persisting traditional practices?

It is likewise regrettable that the geographical analysis of the phenomenon of urbanisation is weakened by the almost complete absence of supporting maps and detailed demographic data. The reader is left wondering which available spaces will receive the bulk of this urban growth: will they be the major metropolitan centres or the mediumsized cities? How would that affect the development of regional organisation? Given the huge dimensions of the urbanisation process in China, these questions are supremely important, and they deserve closer attention in future studies. 